\title{
MICROENCAPSULATION OF PEQUI PULP BY SPRAY DRYING: USE OF MODIFIED STARCHES AS ENCAPSULATING AGENT
}

\author{
AUDIRENE A. SANTANA ${ }^{1}$, RAFAEL A. DE OLIVEIRA ${ }^{2}$, LOUISE E. KUROZAWA ${ }^{3}$, \\ KIL J. PARK ${ }^{4}$
}

\begin{abstract}
The aim of this study was to evaluate the microencapsulation of pequi pulp by spray drying. A central composite rotational design was used in order to evaluate the effect of the independent variables: inlet air temperature, surfactant concentration and modified starch concentration. The dependent variables were assumed as yield of the process and the product features microencapsulated. A selection of the best process condition was performed to obtain the best condition of a product with the highest vitamin $\mathrm{C}$ and carotenoids content. Powders showed moisture content below $2 \%$. The experimental values of hygroscopicity, yield, water activity, total carotenoids and vitamin $\mathrm{C}$ powders ranged from 7.96 to $10.67 \mathrm{~g}$ of adsorbed water $100 \mathrm{~g}$ of solids, 24.34 to $49.80 \%, 0.13$ to $0.30,145.78$ to $292.11 \mathrm{mg}$ of ascorbic acid/g of pequi solids and 15.51 to $123.42 \mathrm{mg}$ of carotenoids/g of pequi solids, respectively. The inlet air temperature $140^{\circ} \mathrm{C}$, the surfactant concentration of $2.5 \%$ and the modified starch concentration of $22.5 \%$ was recommended as the selected condition. By the scanning electron microscopy, it was observed that most of the particles had spherical shape and smooth surface.
\end{abstract}

KEYWORDS: Caryocar brasiliense; spray drying; experimental design; encapsulation; morphology.

\section{MICROENCAPSULAÇÃO DE POLPA DE PEQUI POR SPRAY DRYING: USO DE AMIDO MODIFICADO COMO AGENTE ENCAPSULANTE}

RESUMO: O objetivo deste trabalho foi avaliar a microencapsulação de polpa de pequi por spray drying. Um delineamento composto central rotacional foi utilizado para avaliar o efeito das variáveis independentes: temperatura do ar de entrada, concentração de surfactante e concentração de amido modificado sobre o rendimento do processo e as características do produto microencapsulado. A seleção da melhor condição de processo foi baseada na obtenção de um produto com maior teor de vitamina $\mathrm{C}$ e de carotenoides. Todos os pós produzidos mostraram teores de umidade inferiores a $2 \%$. Os valores experimentais de higroscopicidade, rendimento de secagem, atividade de água, vitamina $\mathrm{C}$ e carotenoides totais dos pós variaram de 7,96 a 10,67 g de água adsorvida/ $100 \mathrm{~g}$ sólidos, 24,34 a 49,80\%, 0,13 a 0,30, 145,78 a 292,11 mg de ácido ascórbico/g de sólidos de pequi e 15,51 a 123,42 mg de carotenoides/g de sólidos de pequi, respectivamente. Temperatura de ar de entrada de $140^{\circ} \mathrm{C}$, concentração de surfactante de $2,5 \%$ e concentração de amido modificado de $22,5 \%$ foram recomendadas como sendo a condição selecionada. Através da microscopia eletrônica de varredura, observou-se que a maioria das partículas apresentou formato esférico e superfície lisa.

PALAVRAS-CHAVE: Caryocar brasiliense; secagem por aspersão; planejamento experimental; encapsulação; morfologia.

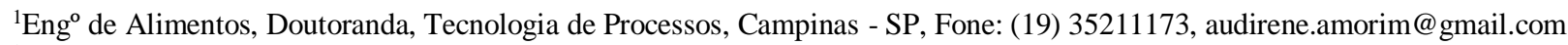

${ }^{2}$ Eng. Agrícola, Prof. Doutor, Tecnologia de Processos, Campinas - SP, augustus@ feagri.unicamp.br

${ }^{3} E_{n}{ }^{\circ}$ de Alimentos, Prof. Doutor, Departamento de Ciência e Tecnologia de Alimentos, Londrina - PR, louise@ uel.br

${ }^{4}$ Eng $^{\circ}$ de Alimentos, Prof. Doutor,Tecnologia de Processos, Campinas - SP, kil@ feagri.unicamp.br

Recebido pelo Conselho Editorial em: 22-11-2013

Aprovado pelo Conselho Editorial em: 24-4-2014
}

Eng. Agríc., Jaboticabal, v.34, n.5, p. 980-991, set./out. 2014 


\section{INTRODUCTION}

Pequi (Caryocar brasiliense Camb.), an oleaginous fruit and rich in carotenoids is grown all over the Brazilian savannah. From all the uses of pequi, the most prominent is in feeding. The large consumption of pequi is due to the peculiar flavor, aroma and also for its high nutritional value (SOUZA and RAMOS, 2011). Because it is rich in carotenoids, this fruit has important biological functions in humans, acting in preventing some types of cancer, inhibition of gastric mucosa against ulcers, in the ability to prevent photosensitization in certain skin diseases, increasing immune response to certain types of infection and the anti-aging properties. In addition, some carotenoids have vitamin A activity as well as protectors of oils and fats, as they are considered captors of oxygen, oxidizing itself preferentially (AQUINO et al., 2009).

Seasonality is a factor limiting the marketing and the population access to pequi because its fruiting occurs mainly between the months of January to March. Dehydration is an alternative to increasing the life of the fruit, a better preservation and an easier transportation, storage and handling of the final product. In this context, spray drying is a good choice. This type of drying is a process of transformation from a liquid fluid to a dry product, in a single operation. It basically consists in the spraying the liquid in a compartment which receives a flow of hot air, so that the rapid evaporation of water allows keeping low the particles temperature. Thus, this technique allows drying of heat-sensitive products (food, pharmaceutical and biological), without overly affecting quality (GHARSALLAOUI et al., 2007).

However, the powders resulting from the drying of fruit pulps usually have some handling problems such as high hygroscopicity and stickiness due to the presence of sugars and low molecular weight acids which have a low glass transition temperature. This can cause adhesion of powder on the walls of the dryer, resulting in low drying yield, difficulty in handling and compaction of the powder, making its storage and use more difficult. In this context, the use of high molecular weight additives in order to increase the glass transition temperature of the product is essential (BHANDARI et al. 1993). In addition to reducing the hygroscopicity of the powders, these additives normally used in the form of microencapsulation for encapsulating agents may protect sensitive food components from adverse environmental conditions (GHARSALLAOUI et al., 2007)

The modified starch provides an excellent retention of volatiles during the spray drying that can be used in high concentration, which shows an increase in viscosity. The use of such encapsulating agents is generally limited by the concentration of solids in the food, while the modified starch can be used at concentrations of about 50\% (REINECCIUS, 1991).

However, as the pequi pulp has high lipid content (up to $33.4 \%$ on a wet basis (LIMA et al., 2007)), using only the modified starch would possibly not be sufficient for the formation of the emulsion. Nevertheless this deficiency can be compensated using a secondary emulsifier for the preparation of the feed solution. The use of surfactants would be an alternative (MASCARENHAS, 2010).

This research aimed to study the influence of the concentration of the encapsulating agent (modified starch), surfactant concentration (Tween 80) and the air temperature in microencapsulation by spray drying of pequi pulp. The process yield and powder properties (moisture content, hygroscopicity, water activity and vitamin $\mathrm{C}$ content and carotenoids retention) were analyzed as responses. From these results was obtained the best condition of microencapsulation process that results in the formation of products with higher concentrations of vitamin $\mathrm{C}$ and carotenoids. Finally, the particles produced, under this condition were evaluated for absolute and bulk density, porosity, particle size distribution and morphology.

\section{MATERIAL AND METHODS}

\section{Material}


The pequi coming from the same batch were acquired in Grande Sertão Cooperative Ltda Montes Claros - MG, Brazil. They were manually selected for removal of poor quality fruits, washed with chlorinated water ( 1.5 to $3 \% \mathrm{p} / \mathrm{v}$ ) and sanitized in aqueous solution of sodium hypochlorite to 200 $\mathrm{mg} / \mathrm{L}$, for 15 minutes. The bark was removed manually with the aid of stainless steel knives. The pyrenes (seeds) were imbedded in an aqueous solution of sodium hypochlorite to $100 \mathrm{mg} / \mathrm{L}$, for 15 minutes. The pulp of pyrene was removed with the aid of stainless steel knives, stored in large plastic polypropylene pots, with lid. These were placed in refrigerated chamber at $10 \pm 1^{\circ} \mathrm{C}$ and relative humidity of $90-95 \%$. In Table 2, the results presented the physicochemical properties of the pequi pulp.

For the microencapsulation process was used modified starch Snow Flake ${ }^{\circledR} \mathrm{E} 6131$ (Corn Products, Mogi Guaçu - SP, Brazil) as the encapsulating agent and Tween 80 with purity PA (Synth, Brazil) as surfactant agent.

\section{Preparation of the extract}

The extract of the pequi pulp used for drying testing in spray dryer was made by mixing one part of pequi pulp to two and half parts of water (weight/weight). This ratio was defined by preliminary tests. Homogenization was performed using a domestic blender (Model MAGD 19108, Arno, Brazil). The mixture was vacuum filtered on porous fabric (TNT) using a Büchner funnel. This procedure was performed in order to remove suspended solids that could block the passage of extract of the dryer sprinkler nozzle.

Subsequently, modified starch and surfactant agent was added to the filtrate obtained in predetermined concentrations by rotational central composite design (Table 3). The dissolution of the mixture was performed in a homogenizer "turrax" type (Dispersor Extratur, Quimis, Brazil) at room temperature and speed of $14,000 \mathrm{rpm}$ for 10 minutes (complete dissolution) and kept under magnetic stirring until complete passage of the mixture in the dryer.

\section{Microencapsulation by spray drying}

For microencapsulation experiments of pequi pulp was used a laboratory spray dryer (Model B191, Büchi, Flawil, Switzerland). The equipment was operated using a dual fluid nozzle type spray with a hole of $0.7 \mathrm{~mm}$ of diameter. The dimensions of the drying chamber are: diameter 110 $\mathrm{mm}$ and height of $435 \mathrm{~mm}$. The drying process was conducted with a constant compressed air flow of $0.6 \mathrm{~m}^{3} / \mathrm{h}$ and air flow of $19 \mathrm{~m}^{3} / \mathrm{h}$. The inlet air temperature was monitored to observe its variation as a function of the adopted parameters in the dryer supply and the product characteristics. The feed mixture was introduced to the drying chamber at room temperature using a peristaltic pump set for a mass flow of $0.20 \mathrm{~kg} / \mathrm{hr}$.

\section{Experimental design}

The tests were performed in accordance with a rotational central composite design $2^{3}$. The independent variables were: Inlet air temperature in the dryer ( $\left.\mathrm{T}_{\text {inl }}\right)$, Tween 80 surfactant concentration $\left(\mathrm{C}_{S}\right)$ and the concentration of modified starch encapsulating agent $\left(\mathrm{C}_{\mathrm{MS}}\right)$. The responses were evaluated in planning: process yield, moisture content, hygroscopicity, water activity, vitamin $\mathrm{C}$ content and retention of total carotenoids. Table 1 show the levels used in the experimental design.

TABLE 1. Levels of the independent variables used in the experimental design.

\begin{tabular}{ccccccc}
\hline \multirow{2}{*}{ Independent variables } & \multirow{2}{*}{ Coded variables } & \multicolumn{5}{c}{ Levels } \\
\cline { 3 - 7 } & & -1.68 & -1 & 0 & 1 & 1.68 \\
\hline $\mathrm{T}_{\text {inl }}\left({ }^{\circ} \mathrm{C}\right)$ & $x_{1}$ & 140 & 152 & 170 & 188 & 200 \\
$\mathrm{C}_{\mathrm{S}}(\%)$ & $x_{2}$ & 0 & 1 & 2.5 & 4 & 5 \\
$\mathrm{C}_{\mathrm{MS}}(\%)$ & $x_{3}$ & 15 & 18 & 22.5 & 27 & 30 \\
\hline
\end{tabular}


The experimental data were adjusted to a second order polynomial equation as shown below:

$$
y=b_{0}+b_{1} x_{1}+b_{2} x_{2}+b_{3} x_{3}+b_{11} x_{1}^{2}+b_{22} x_{2}^{2}+b_{33} x_{3}^{2}+b_{12} x_{1} x_{2}+b_{13} x_{1} x_{3}+b_{23} x_{2} x_{3}
$$

where,

$y=$ the response (dependent variable);

$b_{0}=$ the regression constant;

$b_{1}, b_{2}$ and $b_{3}=$ regression coefficients for linear terms;

$b_{11}, b_{22}$ and $b_{33}=$ the coefficients of quadratic regression;

$b_{12}$ and $b_{13}=$ the coefficients of the interaction terms, and

$x_{1}, x_{2}$ and $x_{3}$ represents the coded values of the independent variables (inlet air temperature in the dryer, surfactant concentration and modified starch concentration, respectively).

\section{Yield of the drying process and Physical-chemical analysis of the powders}

The powders were characterized regarding to the moisture content, hygroscopicity, water activity, vitamin $\mathrm{C}$ and carotenoids. For the powders produced in the selected condition were analyzed: absolute and bulk density, porosity, particle size distribution and morphology.

The drying efficiency was determined as the ratio between the mass of solids in the powder product and the mass of solids in the extract of the pequi pulp used to feed the dryer.

The moisture of the powder was determined gravimetrically using a vacuum oven at $70^{\circ} \mathrm{C}$ up to constant weight. The moisture of the feed solutions formulated with different concentrations of modified starch were determined using an oven with forced circulation at $60^{\circ} \mathrm{C}$ for 24 hours and then in a vacuum oven at $70^{\circ} \mathrm{C}$ until constant weight AOAC (2006).

The hygroscopicity was determined according to the methodology proposed by CAI \& CORKE (2000), with some modifications. Approximately $1 \mathrm{~g}$ of each sample was placed in a sealed container containing a saturated solution of $\mathrm{NaCl}\left(75.29 \%\right.$ relative humidity) at $25^{\circ} \mathrm{C}$ and, after seven days, the samples were weighed and the hygroscopicity was expressed as $\mathrm{g}$ of adsorbed moisture per $100 \mathrm{~g}$ of dry weight of the sample $(\mathrm{g} / 100 \mathrm{~g})$.

The determination of total carotenoids ( $\mathrm{mg} / \mathrm{g}$ of pequi solids) was performed according to the methodology described by RODRIGUES-AMAYA (1999), based on the extraction of acetone and separation in petroleum ether. The color reading was taken in spectrophotometer at $450 \mathrm{~nm}$ wavelength of $\beta$-carotene, the predominant pequi carotenoid.

Determination of vitamin $\mathrm{C}(\mathrm{mg} / \mathrm{g}$ of pequi solids) was performed according to the methodology proposed by the AOAC (2006), which is based on the reduction of 2.6diclorobenzenoindofenol indicator (DCFI) by ascorbic acid.

Water activity was determined using a Decagon (model Pawkit, Aqualab, USA) at $25^{\circ} \mathrm{C}$.

To determine the bulk density $\left(\rho_{a p}\right), 2 \mathrm{~g}$ of the powder were transferred to a graduated cylinder $(10 \mathrm{ml})$. The powder was compacted by striking the beaker 50 times on the bench. The density was calculated by dividing the mass of the powder over the volume occupied by it. Measurements were performed at room temperature.

The absolute density $\left(\rho_{a b s}\right)$ of the samples was determined at $25^{\circ} \mathrm{C}$ in a helium gas pycnometer AccuPyc 1330 Automatic Gas Pycnometer (Micromeritics, Norcross, USA).

The porosity $(\varepsilon)$ of the powders was determined according to Equation 2. 


$$
\varepsilon=1-\frac{\rho_{a p}}{\rho_{a b s}}
$$

where,

$$
\begin{aligned}
& \rho_{a p}=\text { the bulk density }(\mathrm{g} / \mathrm{ml}) \text {, and } \\
& \rho_{a b s}=\text { the absolute density }(\mathrm{g} / \mathrm{ml}) \text { of the sample. }
\end{aligned}
$$

The particle size distribution was determined with a laser diffraction apparatus (Mastersizer S Laser Scattering Spectrometer, Model MAM 5005 - Malvern Instruments Ltd., UK), using isopropanol as the liquid sedimentator, since the solubility of the particles does not occur in this liquid. A coupled to the ultrasound equipment was used to increase the dispersibility of the sample. The average diameter was determined based on the average volumetric diameter of time (Brouckere diameter, D [4.3]) usually used to characterize powder particles. For this analysis, a small amount of product was dispersed in isopropanol and subjected to 10 readings of size distribution particles.

The microstructure of the powders was evaluated by a scanning electronic microscopy (SEM). The samples were fixed to metallic specimens door (stubs), with a double-sided adhesive tape conventional conductive. They were metallized with an alloy of gold / palladium in a Polaron SC7620 Sputter coater (Ringmer, UK), at a rate of coverage of $0.51 \AA$ / s for 180 seconds with 3-5 $\mathrm{mA}$ current 1 Volt and $2^{\prime} 10^{-2} \mathrm{~Pa}$. The samples were then observed in a scanning electronic microscope LEO440i (LEICA Electron microscopy Ltd., Cambridge, UK), operating at $5 \mathrm{kV}$. Image acquisition was performed by LEO software, version 3.01.

\section{RESULTS AND DISCUSSION}

The main characteristics of the pequi pulp are shown in Table 2.

TABLE 2. Physicochemical properties of the pequi pulp and filtered pequi pulp.

\begin{tabular}{cccc}
\hline Analysis & $\begin{array}{c}\text { Average value } \\
\text { of the pulp }\end{array}$ & $\begin{array}{c}\text { Average value } \\
\text { of the filtered pulp }\end{array}$ & Method \\
\hline Moisture content (\%, wet basis) & $52.3 \pm 0.02$ & $88.59 \pm 0.00$ & AOAC (2006) \\
Protein (\% dry basis) & $5.08 \pm 0.03$ & $3.81 \pm 0.07$ & AOAC (2006) \\
Lipids of the pulp (\% dry basis) & $30.66 \pm 0.75$ & $19.99 \pm 1.02$ & AOAC (2006) \\
Ashes (\%) & $1.22 \pm 0.001$ & $0.35 \pm 0.18$ & AOAC (2006) \\
Total fiber content & $18.37 \pm 0.67$ & - & AOAC (2006) \\
Total sugars (\% dry basis) & $5.30 \pm 0.04$ & $4.56 \pm 0.03$ & AOAC (2006) \\
Reducing sugars (\% dry basis) & $5.04 \pm 0.71$ & $4.12 \pm 0.43$ & AOAC (2006) \\
Titratable acidity (\% citric acid) & $1.50 \pm 0.14$ & $1.33 \pm 0.06$ & AOAC (2006) \\
pH & $6.97 \pm 0.17$ & $6.23 \pm 0.09$ & pH Metro \\
Total Soluble Solids ( ${ }^{\circ}$ Brix) & $20.09 \pm 0.78$ & $8.49 \pm 0.47$ & Countertop refractometer \\
Vitamin C (mg / g solid pequi) & $338.38 \pm 1.06$ & $335.06 \pm 0.81$ & AOAC (2006) \\
Carotenoids (mg / g solid pequi) & $140.69 \pm 0.08$ & $138.41 \pm 0.04$ & Rodrigues-Amaya (1999) \\
\hline
\end{tabular}

$\mathrm{AOAC}=$ Association of Analytical Chemists; - = Has not been determined.

\section{Experimental design}

The values of process yield, moisture powder content, hygroscopic, water activity and content of vitamin $\mathrm{C}$ and carotenoids as well as the inlet temperature of the air, are shown in Table 3. 
TABLE 3. Responses of experimental design for pequi pulp powder using modified starch as encapsulating agent.

\begin{tabular}{|c|c|c|c|c|c|c|c|c|c|c|}
\hline TREATMENTS & $\begin{array}{l}\underset{\text { Tinl }}{{ }^{\circ}} \\
\left({ }^{\circ} \mathrm{C}\right)\end{array}$ & $\begin{array}{l}\mathrm{Cs} \\
(\%)\end{array}$ & $\begin{array}{l}\mathrm{C}_{\mathrm{MA}} \\
(\%)\end{array}$ & $\begin{array}{c}\text { Humidity } \\
(\%)\end{array}$ & $\begin{array}{l}\text { Higroscopicity } \\
\text { (g water } \\
\text { adsorbed } / 100 \mathrm{~g} \\
\text { solids) }\end{array}$ & Yield (\%) & $A_{w}$ & $\begin{array}{c}\text { Vitamin } \\
\mathrm{C} \text { (mg/g solids } \\
\text { of pequi) }\end{array}$ & $\begin{array}{l}\text { Total carotenoids } \\
\text { (mg/g sólids of pequi) }\end{array}$ & $\begin{array}{l}T_{\text {exit }} \\
\left({ }^{\circ} \mathrm{C}\right)\end{array}$ \\
\hline 1 & $152(-1)$ & $1(-1)$ & $18(-1)$ & $1.05 \pm 0.001$ & $9.58 \pm 0.001$ & 40.02 & $0.15 \pm 0.004$ & $286.68 \pm 0.77$ & $119.37 \pm 0.002$ & $95 \pm 0.5$ \\
\hline 2 & $188(+1)$ & $1(-1)$ & $18(-1)$ & $0.47 \pm 0.001$ & $9.86 \pm 0.002$ & 49.80 & $0.13 \pm 0.001$ & $234.01 \pm 0.91$ & $48.93 \pm 0.01$ & $111 \pm 0.6$ \\
\hline 3 & $152(-1)$ & $4(+1)$ & $18(-1)$ & $1.12 \pm 0.001$ & $10.15 \pm 0.001$ & 37.54 & $0.20 \pm 0.01$ & $155.32 \pm 0.65$ & $99.34 \pm 0.11$ & $88 \pm 0.6$ \\
\hline 4 & $188(+1)$ & $4(+1)$ & $18(-1)$ & $1.26 \pm 0.002$ & $8.95 \pm 0.002$ & 40.02 & $0.25 \pm 0.01$ & $242_{. \mu} .7 \pm 0.90$ & $67.79 \pm 0.02$ & $114 \pm 1.0$ \\
\hline 5 & $152(-1)$ & $1(-1)$ & $27(+1)$ & $1.91 \pm 0.005$ & $9.54 \pm 0.001$ & 34.89 & $0.21 \pm 0.003$ & $259.28 \pm 0.74$ & $80.95 \pm 0.03$ & $93 \pm 0.3$ \\
\hline 6 & $188(+1)$ & $1(-1)$ & $27(+1)$ & $1.49 \pm 0.003$ & $8.95 \pm 0.002$ & 35.80 & $0.19 \pm 0.01$ & $289.97 \pm 0.65$ & $80.10 \pm 0.01$ & $115 \pm 1.0$ \\
\hline 7 & $152(-1)$ & $4(+1)$ & $27(+1)$ & $1.77 \pm 0.005$ & $9.65 \pm 0.001$ & 25.60 & $0.19 \pm 0.001$ & $231.38 \pm 0.62$ & $98.48 \pm 0.004$ & $94 \pm 1.2$ \\
\hline 8 & $188(+1)$ & $4(+1)$ & $27(+1)$ & $1.92 \pm 0.001$ & $9.27 \pm 0.001$ & 36.03 & $0.24 \pm 0.01$ & $252.73 \pm 0.99$ & $109.55 \pm 0.003$ & $115 \pm 0.4$ \\
\hline 9 & $140(-1,68)$ & $2.5(0)$ & $22.5(0)$ & $1.79 \pm 0.001$ & $7.96 \pm 0.001$ & 42.99 & $0.28 \pm 0.001$ & $292.11 \pm 0.62$ & $123.42 \pm 0.001$ & $82 \pm 0.2$ \\
\hline 10 & $200(+1,68)$ & $2.5(0)$ & $22.5(0)$ & $0.43 \pm 0.003$ & $10.67 \pm 0.001$ & 33.16 & $0.25 \pm 0.01$ & $190.98 \pm 0.51$ & $15.51 \pm 0.002$ & $115 \pm 0.7$ \\
\hline 11 & $170(0)$ & $0(-1,68)$ & $22.5(0)$ & $0.65 \pm 0.001$ & $8.78 \pm 0.001$ & 44.73 & $0.30 \pm 0.03$ & $277.30 \pm 0.96$ & $35.92 \pm 0.004$ & $105 \pm 0.2$ \\
\hline 12 & $170(0)$ & $5(+1,68)$ & $22.5(0)$ & $1.47 \pm 0.002$ & $8.86 \pm 0.002$ & 24.34 & $0.23 \pm 0.01$ & $145.78 \pm 0.89$ & $82.04 \pm 0.04$ & $105 \pm 0.9$ \\
\hline 13 & $170(0)$ & $2.5(0)$ & $15(-1,68)$ & $1.30 \pm 0.005$ & $9.59 \pm 0.002$ & 41.18 & $0.27 \pm 0.004$ & $254.50 \pm 0.54$ & $84.85 \pm 0.02$ & $102 \pm 0.4$ \\
\hline 14 & $170(0)$ & $2.5(0)$ & $30(+1,68)$ & $0.66 \pm 0.002$ & $9.34 \pm 0.01$ & 25.80 & $0.20 \pm 0.02$ & $192.41 \pm 0.39$ & $53.61 \pm 0.01$ & $102 \pm 0.3$ \\
\hline 15 & $170(0)$ & $2.5(0)$ & $22.5(0)$ & $1.39 \pm 0.001$ & $9.99 \pm 0.01$ & 40.65 & $0.26 \pm 0.02$ & $213.26 \pm 0.86$ & $57.97 \pm 0.002$ & $100 \pm 0.2$ \\
\hline 16 & $170(0)$ & $2.5(0)$ & $22.5(0)$ & $1.35 \pm 0.003$ & $9.99 \pm 0.001$ & 40.71 & $0.27 \pm 0.01$ & $215.36 \pm 0.51$ & $57.50 \pm 0.01$ & $97 \pm 0.1$ \\
\hline 17 & $170(0)$ & $2.5(0)$ & $22.5(0)$ & $1.37 \pm 0.004$ & $9.89 \pm 0.003$ & 41.20 & $0.26 \pm 0.02$ & $215.91 \pm 0.35$ & $58.28 \pm 0.003$ & $95 \pm 0.1$ \\
\hline
\end{tabular}

$\mathrm{T}_{\mathrm{inl}}=$ temperature of inlet air in the dryer, $\mathrm{CS}=$ concentration of surfactant $\mathrm{C}_{\mathrm{MS}}=$ concentration of modified starch, $\mathrm{T}_{\mathrm{exit}}=$ exit temperature, * Values in parentheses correspond to the coded values of independent variables.

Table 4 shows the regression coefficients coded in Equation 1, the values of $F_{\text {calculated }}$ and $\mathrm{F}_{\text {tabulated }}$ and coefficients of determination $\left(\mathrm{R}^{2}\right)$. After elimination of non-significant factors, was verified the significance of regression and lack of adjustment at a significance level of $10 \%$, through an Analysis of Variance (ANOVA) using the F test.

TABLE 4. Second order coded regression coefficients of the responses powder moisture content, hygroscopicity, yield, water activity, vitamin $\mathrm{C}$ and total carotenoids content.

\begin{tabular}{ccccccc}
\hline Coefficients & $\begin{array}{c}\text { Moisture } \\
(\%)\end{array}$ & $\begin{array}{c}\text { Hygroscopicity } \\
\text { (g adsorbed } \\
\text { water/100g solids })\end{array}$ & $\begin{array}{c}\text { Yield } \\
(\%)\end{array}$ & $\mathrm{A}_{\mathrm{w}}$ & $\begin{array}{c}\text { Vitamin C (mg/g } \\
\text { solids of pequi) }\end{array}$ & $\begin{array}{c}\text { Carotenoids (mg/g } \\
\text { solids of pequi) }\end{array}$ \\
\hline$\beta_{0}$ & 1.35 & 9.93 & 40.70 & 0.27 & 213.46 & 56.52 \\
$\beta_{1}$ & $\mathrm{~ns}$ & $\mathrm{~ns}$ & 2.94 & $\mathrm{~ns}$ & $\mathrm{~ns}$ & -20.01 \\
$\beta_{11}$ & $\mathrm{~ns}$ & $\mathrm{~ns}$ & $\mathrm{~ns}$ & $\mathrm{~ns}$ & $\mathrm{~ns}$ & $\mathrm{~ns}$ \\
$\beta_{2}$ & $\mathrm{~ns}$ & $\mathrm{~ns}$ & -4.07 & $\mathrm{~ns}$ & -29.93 & $\mathrm{~ns}$ \\
$\beta_{22}$ & $\mathrm{~ns}$ & $\mathrm{~ns}$ & $\mathrm{~ns}$ & $\mathrm{~ns}$ & $\mathrm{~ns}$ & $\mathrm{~ns}$ \\
$\beta_{3}$ & $\mathrm{~ns}$ & $\mathrm{~ns}$ & $\mathrm{~ns}$ & $\mathrm{~ns}$ & $\mathrm{~ns}$ & $\mathrm{~ns}$ \\
$\beta_{33}$ & $\mathrm{~ns}$ & $\mathrm{~ns}$ & -4.46 & $\mathrm{~ns}$ & $\mathrm{~ns}$ & $\mathrm{~ns}$ \\
$\beta_{12}$ & $\mathrm{~ns}$ & $\mathrm{~ns}$ & -2.06 & $\mathrm{~ns}$ & $\mathrm{~ns}$ & $\mathrm{~ns}$ \\
$\beta_{13}$ & $\mathrm{~ns}$ & $\mathrm{~ns}$ & $\mathrm{Ns}$ & $\mathrm{ns}$ & $\mathrm{ns}$ & 14.02 \\
$\beta_{23}$ & $\mathrm{~ns}$ & $\mathrm{~ns}$ & $\mathrm{~ns}$ & $\mathrm{~ns}$ & $\mathrm{~ns}$ & $\mathrm{~ns}$ \\
$F_{\text {calculated }}$ & $\mathrm{ns}$ & $\mathrm{ns}$ & 15.41 & $\mathrm{~ns}$ & 9.90 & 7.09 \\
$F_{\text {tabulated }}$ & $\mathrm{ns}$ & $\mathrm{ns}$ & 2.45 & $\mathrm{~ns}$ & 3.07 & 2.73 \\
$R^{2}$ & $\mathrm{~ns}$ & $\mathrm{~ns}$ & 0.88 & $\mathrm{~ns}$ & 0.40 & 0.50 \\
\hline
\end{tabular}

ns = not significant at a $\mathrm{p}>0.10$.

\section{Yield of the drying process}

From the experimental yields data reported in Table 3, it was observed that they ranged from 24.34 to $49.80 \%$. These values were similar to those obtained by TONON et al. (2008) on the 
drying of assai pulp in spray dryer. The proposed model for prediction of yield model showed $\mathrm{R}^{2}$ of 0.88 , indicating that the model explained $88 \%$ of variance of the observed data. Through the Analysis of Variance (ANOVA) using the F-test, regression and lack of adjustment of the model presented is significant at $90 \%$ confidence, since $F_{\text {calculated }}$ was superior to $F_{\text {tabulated. Thus, the set }}$ model was considered predictive.

Figure $1(\mathrm{a}, \mathrm{b})$ shows the response surfaces generated via the proposed model expressing the interaction between two variables, while the third was kept at the central point. The highest yields were obtained at higher temperatures and lower concentrations of encapsulating agent and surfactant. TONON et al. (2008) also found a positive influence of temperature on the yield of drying on assai pulp spray dryer. According to the authors, this result may be related to the fact that heat transfer and mass that occurs during drying be most effective when performed at higher temperatures.

Regarding the encapsulating agent (Figure 1a), the higher the concentration, the lower yield of the process. This may be related to the increased viscosity of feed which results in production of larger droplets sprayed inside the drying chamber. These larger droplets are more difficult to dry as they become wetter particles, which tend to stick more in the wall dryer or this fact also can be related to the difficulty of water diffusion through the droplet.

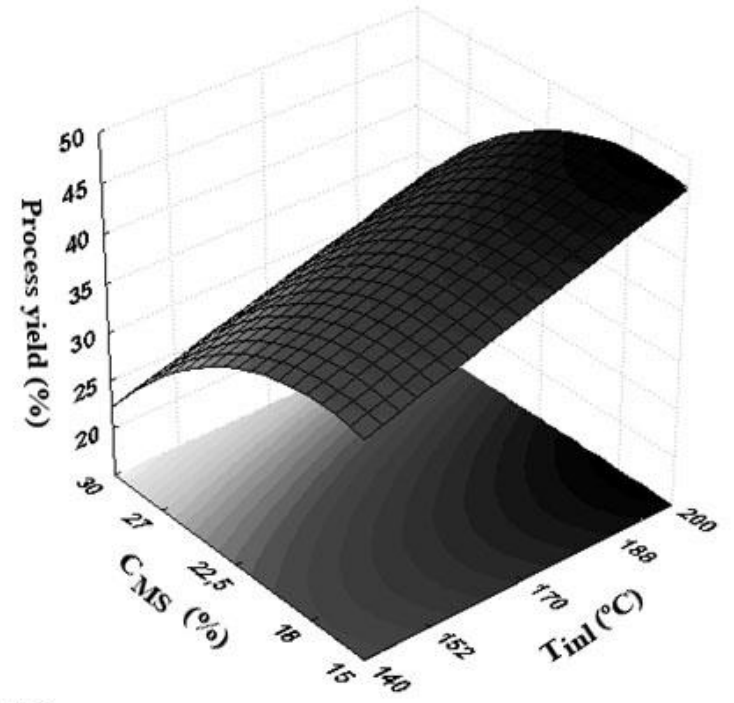

(a)

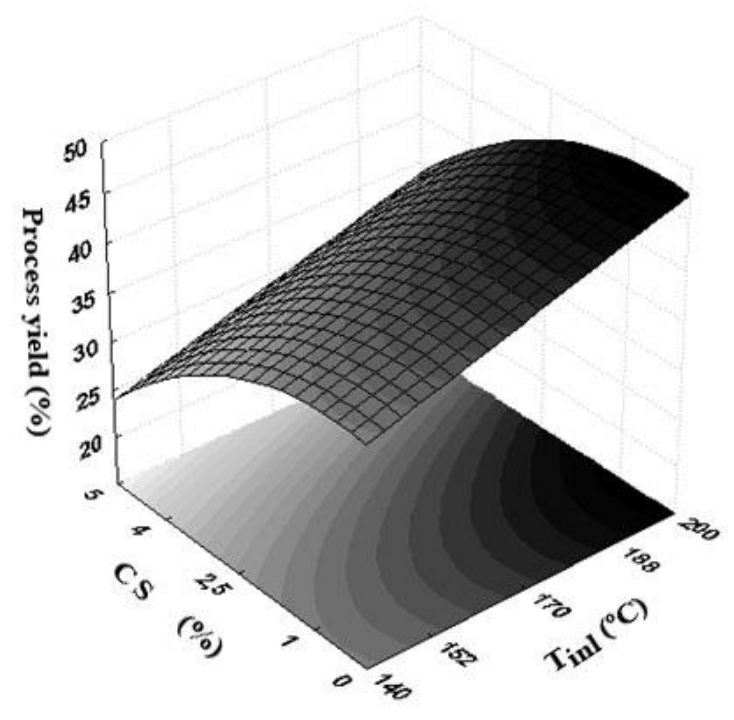

(b)

FIGURE 1. Response surfaces for yield (\%) of powders pequi pulp encapsulated with modified starch in function of $\mathrm{T}_{\mathrm{inl}}$ and $\mathrm{C}_{\mathrm{MS}}(\mathrm{a})$ and $\mathrm{T}_{\text {inl }}$ and $\mathrm{C}_{\mathrm{S}}(\mathrm{b})$

Figure $1 \mathrm{~b}$ shows the effect of surfactant concentration on the yield, in which highest yield was obtained at low concentrations of Tween 80 (up to 1\%). Increasing the amount of this addictive was observed a decrease in yield of drying. MASCARENHAS (2010), studying the microencapsulation of linseed oil, found that concentrations above $0.2 \%$ were not favoring the formation of the emulsion. Normally the less stable the emulsion, the lower the encapsulation efficiency, that is, the larger the amount of non-emulsified material present on the surface of the particles (BARBOSA et al., 2005). A larger amount of non-emulsified materials favors the adhesion of microcapsules in the drier chambers, thus reducing the yield of the process. The use of emulsifier in excess also leads to destabilization of the phases and leads to coalescence of the formed droplets.

\section{Humidity, water activity and hygroscopicity}

All the powders produced show inferior moisture to $2 \%$ (Table 2). These results are in agreement with those reported by Barroso et al. (2014) in the drying linseed oil by spray dryer. The moisture is an important property of powdered products, since it is an indicator of the drying 
efficiency, and together with the temperature affects the shelf life and adhesiveness of the powdered product, since the ability of water to act as plasticizing agent is limited, decreasing the glass transition temperature. In general, moisture content between 3-10\% in dry food has good stability during storage (KLAYPRADIT \& HUANG, 2008).

The values of water activity of the particles ranging from 0.13 to 0.30 . These values are within the limit of 0.30 , which, according to QUEK et al. (2007), is positive for powder stability. The non-enzymatic browning, major deterioration reactions, exhibits very low speed in this range of $\mathrm{A}_{\mathrm{w}}$. However, the amount of water present in the matrix can affect the oxidative stability of lipids. Lower speed on oxidation process of lipids is observed for values of water activity between 0.20 and 0.37 . The rate of oxidation increases for lower values and the ones very close to zero or higher (state of dehydration). Similar tracks were obtained for TONON et al. (2011).

The hygroscopicity of the powders ranged from 7.96 to $10.67 \mathrm{~g}$ adsorbed water $/ 100 \mathrm{~g}$ solids. These values are well below to those found by TONON et al. (2008) for dry assai pulp by spray drying using maltodextrin as carrier agent. This fact can be related to the raw material studied, because pequi has higher lipid content than assai and it is less hygroscopic.

The moisture, $A_{w}$ and hygroscopicity of pequi pulp powder were not statistically influenced by the independent variables, indicating that, within the studied temperature of the inlet air in the dryer, surfactant concentration and concentration of modified starch in this study, the values of these responses did not differ significantly (Table 4).

\section{Content of vitamin $\mathrm{C}$ and total carotenoids}

The vitamin $\mathrm{C}$ content of microencapsulated powders with modified starch ranged from 145.78 to $292.11 \mathrm{mg}$ of ascorbic acid / g solid pequi and carotenoid content ranged from 15.51 to $123.42 \mathrm{mg}$ of carotenoids / $\mathrm{g}$ of pequi solids.

The final contents in vitamin $\mathrm{C}$ was significantly influenced by the concentration of surfactant, which has negative effects on vitamin $\mathrm{C}$, that is the increase in this parameter resulted in lower value of the dependent variable. This might be due to high concentrations of surfactant not promote the formation of an emulsion which results in more pequi in the surface of the capsule and therefore, more degradation of vitamin $\mathrm{C}$. The carotenoid content suffered negative influence in the inlet air temperature, indicating that at lower temperature ranges are obtained the highest values of total carotenoids, which is due to the high thermal sensitivity of this pigment .

The coefficients of determination $\left(\mathrm{R}^{2}\right)$ for models adjusted for replies vitamin $\mathrm{C}$ and total carotenoids were 0.40 and 0.50 , respectively, values considered very low, being not possible to obtain predictive models and response surfaces.

\section{Selection of the best process condition}

The selection of the best process condition of microencapsulation by spray drying of pequi pulp with modified starch as the encapsulating agent was performed in order to obtain larger amounts of vitamin $\mathrm{C}$ and total carotenoids content. Thus, the inlet air temperature of $140{ }^{\circ} \mathrm{C}$, the surfactant concentration of $2.5 \%$ and the concentration of modified starch to $22.5 \%$ were recommended as selected condition.

\section{Bulk density, porosity and absolute density}

The knowledge of the density of the product is important for processing, packaging, storage and transport, since it indicates how much material by weight, it may contain in a given volume. Low bulk density of a product is not attractive, resulting in a larger volume packaging. In addition, the product contains a greater amount of air in contact and then there is a greater possibility of food be oxidized (BARBOSA-CANOVAS \& JULIAN, 2005; CAI \& CORKE, 2000).

The pequi pulp in microencapsulated powder with modified starch showed value of bulk density of $340 \pm 0.003 \mathrm{~kg} / \mathrm{m}^{3}$. This value was similar to those obtained for microcapsules of 
vegetable oil (TURCHIULI, 2005), linseed oil (CARNEIRO et al., 2012), essential oil of oregano (BROTEL et al., 2012) and essential oil of Rosemary (FERNANDES et al., 2013).

The absolute density of the powder of pequi pulp produced with modified starch was $1300 \pm$ $0.01 \mathrm{~kg} / \mathrm{m}^{3}$. It corresponds to the actual density of the solid and does not include spaces present between the particles, unlike the bulk density, which takes into account all such spaces. These results are expressed in the calculation of the inter-granular porosity, which precisely measures that amount of spaces.

The porosity is an important property in the case of particulate product in which the material is susceptible to oxidation reactions, for example. The largest volume of empty space implies the presence of a larger amount of oxygen, which can cause more rapid oxidation of the lipid protected compound. Pequi pulp powder produced with modified starch had a porosity of $73 \%$, which could reduce its stability, because it contains higher content of oxygen available for oxidative reactions. On the other hand, provides greater capillary porosity, which is of fundamental importance for the reconstitution of the powder in aqueous solution. SANTANA et al. (2013) and TONON et al. (2010) found values of porosity for powders of pequi and assai pulp with gum arabic and maltodextrine 67 and $75 \%$, respectively, values close to these obtained in this study for pequi pulp.

\section{Particle size distribution and average particle diameter}

Particle size is one of the most important physical parameters of the particle product and can influence the mix of different components in the compaction and segregation of the mixture, in which smaller particles remain distributed on the bottom, while larger particles tend to stay on top packaging. Also products with very small particles exhibit low solubility and fluidity (TOTH \& PALLAI-VARSANYI, 2006). Figure 2 shows the particle size distribution obtained for pequi pulp microencapsulated with modified starch.

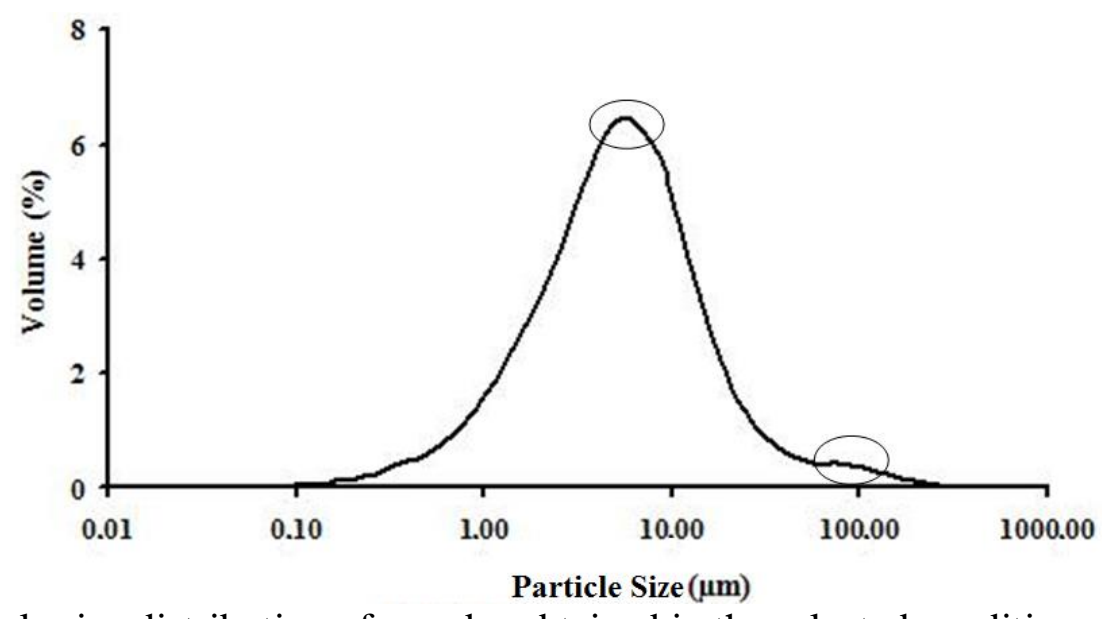

FIGURE 2. Particle size distribution of powder obtained in the selected condition.

The particles have a bimodal distribution indicating two predominant size of particle (Figure 2). The first had diameters ranging between 0.20 and $90 \mu \mathrm{m}$, with volume between 0.2 and $6.5 \%$, respectively. The second peak showed volume lower than $1 \%$ and and diameter between 90 and 500 $\mu \mathrm{m}$.

The presence of particles of smaller size can be attributed to particles of the encapsulating agent who failed to encapsulate the pequi pulp, or particles of juice that were not encapsulated. On the other hand, the presence of larger microcapsules may be due to a possible start of agglomeration, where occur the bridge formation between them (TONON et al., 2010). The pequi pulp particles showed D [4.3] of $9.42 \pm 0.2 \mu \mathrm{m}$. This value was close to those obtained by FERRARI et al. (2012) for blackberry pulp powder with arabic gum on spray dryer. Particle size can also be related to the bulk density of the powder. In general, the density decreases as the particle size increases. The 
larger the average diameter, the greater the content of interstitial air between the microcapsules and therefore, the higher its volume, resulting in low density (GOULA \& ADAMOPOULOS, 2010).

\section{Microscopy of the particle}

The knowledge of the shape of particles is important because it can affect certain factors such as flowability of the powder, packing and interaction with fluids. The MEV images of a mixed population of microspheres (Figure 3) revealed absence of fissures, cracks or collapses, indicating formation of a continuous film on the external wall of the microspheres. So the good sphericity and the absence of cavities (or cracking) may explain the higher encapsulation efficiency (LEIMANN, 2008).
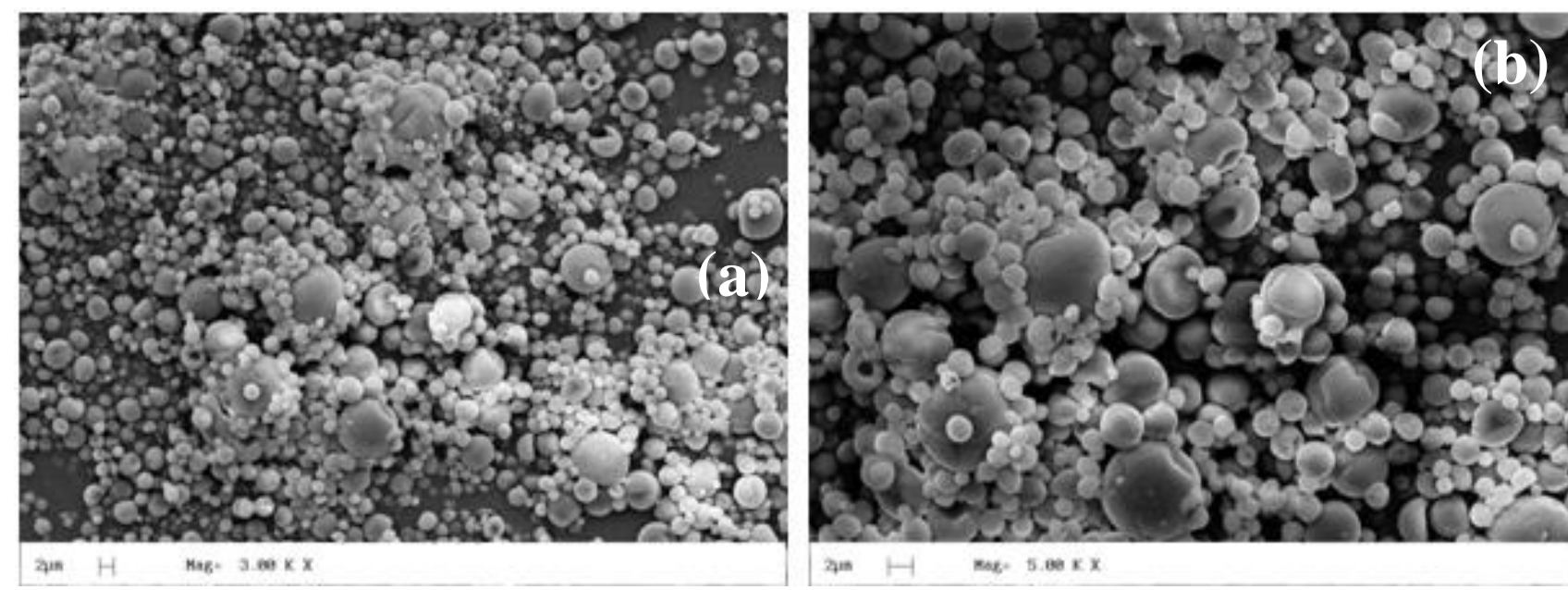

FIGURE 3. Micrographs (SEM) of pequi pulp microencapsulated with modified starch, obtained from the selected condition, with magnification of: (a) 3,000 times and (b) 5,000 times.

Powder produced by spray drying has particles with such characteristics. Smooth and spherical particles are desirable because there is greater retention of flavor (less relative surface ratio area: volume), higher bulk densities (better packing of the powder) and better flow. According to OSÓRIO et al. (2010), smooth spheres are desirable for the stability of the encapsulated ingredients, and for controlled release. Moreover, surface imperfections occur when there is a slow formation of surface crust on the particle during the drying of the sprayed droplets. The presence of teeth has an adverse effect on the flow properties of the product (ROSENBERG et al., 1985).

\section{CONCLUSIONS}

The results obtained in the experimental design indicated that the independent variables of the microencapsulation process showed no significant influence on the yield responses, humidity, water activity and hygroscopicity. The $\mathrm{R}^{2}$ values for the vitamin $\mathrm{C}$ responses and total carotenoids were considered very low and it was possible to obtain models and response surfaces. Of all the responses studied, it was possible to obtain only the model to predict the yield of the process. Based on these results, was selected the following condition of microencapsulation for pequi pulp: $140^{\circ} \mathrm{C}$ for the temperature of inlet dryer air for surfactant concentration of $2.5 \%$ and $22.5 \%$ for the concentration of modified starch. The particles obtained in the selected condition revealed the formation of spherical and smooth microcapsules with varying sizes.

\section{ACKNOWLEDGEMENT}

To FAPESP for doctoral scholarship (Proc. 2009/54170-9) and AEC / UNICAMP. 


\section{REFERENCES}

A.O.A.C. Official Methods of Analysis. $18^{\text {th }}$ ed. Gaithersburg: Association of Official Analytical, 2006.

AQUINO, L. P.; FERRUA, F. Q.; BORGES, S. V.; ANTONIASSI, R.; CORREA, J. L. G.; CIRILLO, M. A. Influência da secagem do pequi (Caryocar brasiliense Camb.) na qualidade do óleo extraído. Ciência Tecnologia de Alimentos, Campinas, v.29, n.2, 2009.

BARBOSA, M. I. M. J.; BORSARELLI, C. D.; MERCADANTE, A. Z. Light stability of spraydried bixin encapsulated with different edible polysaccharide preparations. Food Research International, Kidlington, v.38, n.8-9, p.989-994, 2005.

BARBOSA-CANOVAS, G. V.; JULIANO, P. Physical and chemical properties of food powders. In: ONWULATA, C. (Ed.). Encapsulated and powdered foods, Boca Raton: Taylor \& Francis, Chapter 3, p.39-71, 2005.

BARROSO, A. K. M.; PIERUCCI, A. P. T. R.; FREITAS, S. P.; TORRES, A. G.; ROCHA-LEÃO, M. H. M. Oxidative stability and sensory evaluation of microencapsulated flaxseed oil. Journal of Microencapsulation, London, v.32, n.2, p.193-201.

BHANDARI, B. R.; SENOUSSI, A.; DUMOULIN, E. D.; LEBERT, A. Spray drying of concentrated fruit juices. Drying Technology, Philadelphia, v.11, n.5, p.1081-1092, 1993.

BOTREL, D. A.; BORGES, S. V.; FERNANDES, R. V. B.; VIANA, A. D.; COSTA, J. M. G.; MARQUES, G. R. Evaluation of spray drying conditions on properties of microencapsulated oregano essential oil. International Journal of Food Science and Technology, Oxford, v.47, n.11, p.2289-2296, 2012.

CAI, Y. Z.; CORKE, H. Production and properties of spray-dried Amaranthus betacyanin pigments. Journal of Food Science, Chicago, v.65, n.6, p.1248-1252, 2000.

CARNEIRO, H. C. F.; TONON, R. V.; GROSSO, C. R. F.; HUBINGER, M. D. Encapsulation efficiency and oxidative stability of flaxseed oil microencapsulated by spray drying using different combinations of wall materials. Journal of Food Engineering, Essex, v.115, nº.4, p.443-451, 2013.

FERRARI, C. C.; GERMER, S. P. M.; ALVIM, I. D.; VISSOTTO, F. Z.; AGUIRRE, J. M. Influence of Carrier agents on the physicochemical properties of blackberry powder produced by spray drying. Food Science Technology, Zurich, v.47, p.1237-1245, 2012.

FERNANDES, R. V. B.; BORGES, S. V.; BOTREL, D. A. Influence of spray drying operating conditions on microencapsulated rosemary essential oil properties. Ciência e Tecnologia de Alimentos, Campinas, v.33, n.1, p.171-178, 2013.

GHARSALLAOUI, A.; ROUDAUT, G.; CHAMBIN, O.; VOILLEY, A.; SAUREL, R. Applications of spray drying in microencapsulation of food ingredients: An overview. Food Research International, Barking, v.40, n.9, p.1107-1121, 2007.

GOULA, A. M.; ADAMOPOULOS, K. G. A new technique for spray drying orange juice concentrate. Innovative Food Science and Emerging Technologies, Amsterdam, v.11, n.2, p.342$351,2010$.

KLAYPRADIT, W.; HUANG, Y-W. Fish oil encapsulation with chitosan using ultrasonic atomizer. LWT-Food Science. Technologl, Zurich, v.41, p.1133-1139, 2008.

LEIMANN, F. V. Microencapsulação de óleo essencial de capim-limão utilizando o processo de coacervação simples. 2008. 120 f. Dissertação (Mestrado em Engenharia de Alimentos) Universidade Federal de Santa Catarina, Florionópolis, 2008. 
LIMA, A.; SILVA, A. M. O.; TRINDADE, R. A.; TORRES, R. P.; MANCINI-FILHO, J. Composição química e compostos bioativos presentes na polpa e na amêndoa de pequi (Caryocar brasiliense Camb.). Revista Brasileira de Fruticultura, Jaboticabal, v.29, n.3, p.695-697, 2007.

MASCARENHAS, M. C. C. N. Utilização de surfactantes na produção de microencapsulados de óleo rico em ômega 3 por coacervação complexa com aplicação em emulsões. 2010. $167 \mathrm{f}$. Dissertação (Mestrado em Tecnologia de Alimentos) - Universidade Estadual de Campinas, Faculdade de Engenharia de Alimentos, Campinas, 2010.

OSORIO, C.; ACEVEDO, B.; HILLEBRAND, S.; CARRIAZO, J.; WINTERHALTER, P.; MORALES, A. L. Microencapsulation by spray drying of anthocyanin pigments from corozo (Bactris guineensis) fruit. Journal of Agricultural and Food Chemistry, Washington, v.58, p.69776985, 2010.

QUEK, S.Y.; CHOK, N. K.; SWEDLUND, P. The physicochemical properties of spray dried watermelon powders. Chemical Engineering and Processing, Lausanne, v.46, n.5, p.386-392, 2007.

RAMOS, K. M. C.; SOUZA, V. A. B. Características físicas e químico-nutricionais de frutos de pequizeiro (Caryocar Coriaceum Wittm.) em populações naturais da região meio-norte do Brasil. Revista Brasileira de Fruticultura, Jaboticabal, v. 33, n. 2, p. 500-508, 2011.

REINECCIUS, G.A. Carbohydrates for flavor encapsulation. Food Technology, Chicago, v.45, n.3, p.144-146, 1991.

RODRIGUES-AMAYA, D. B. A. Guide to carotenoid analysis in food. Washington: ILSI Human Nutrition Institute, 1999.

ROSENBERG, M.; KOPELMAN, I. J.; TALMON, Y. A scanning electron microscopy study of microencapsulation. Journal of Food Science, Chicago, v.50, n.1, p.139-144, 1985.

SANTANA, A. A.; KUROZAWA, L. E.; OLIVEIRA, R. A.; PARK, K. J. Influence of process conditions on the physicochemical properties of pequi powder produced by spray drying. Drying Technology, Philadelphia, v.31, p.825-836, 2013.

TONON, R. V.; BRABET, C.; HUBINGER, M. D. Influence of process conditions on the physicochemical properties of açaí (Euterpe oleraceae Mart.) powder produced by spray drying. Journal of Food Engineering, Oxford, v.88, n.3, p.411-418, 2008.

TONON, R. V.; BRABET, C.; HUBINGER, M. D. Anthocyanin stability and antioxidant activity of spray dried açaí (Euterpe oleracea Mart.) juice powder produced with different carrier agents. Food Research International, Kidlington, v.43, p.907-914, 2010.

TONON, R. V.; FREITAS, S. S.; HUBINGER, M. D. Spray drying of açai (Euterpe oleracea Mart.) juice: effect of inlet air temperature and type of carrier agent. Journal of Food Processing and Preservation, Trumbull, v.35, p.691-700, 2011.

TOTH, J.; PALLAI-VARSANYI, E. Drying of bovine serum albumin on inert particle surface in msb dryer. In: INTERNATIONAL DRYING SYMPOSIUM, 15, 2006, Budapeste.

Procedings...p.1216-1222.

TURCHIULI, C.; FUCHS, M.; BOHIN, M.; CUVELIER, M. E.; ORDONNAUD, C.; PEVRATMAILLARD, M. N.; DUMOULIN, E. Oil encapsulation by spray drying and fluidized bed agglomeration. Innovative Food Science and Emerging Technologies, Amsterdam, v.6, n.1, p.29$35,2005$. 